\title{
Prospects for green hydrogen production in the regions of Russia
}

\author{
Liudmila Nefedova*, Kirill Degtyarev, Sophia Kiseleva, Mikhail Berezkin \\ Lomonosov Moscow State University, Geographic Faculty, 119991 Leninskie gory, 1, GSP-1 \\ Moscow, Russian Federation
}

\begin{abstract}
The article discusses the possibilities of hydrogen production using renewable energy sources in Russia for energy storage and for export. The global trends in the development of green hydrogen energy reducing the $\mathrm{CO} 2$ emission are highlighted. The analysis of the potential for hydrogen production in regions of Russia using electricity from operating wind power plants (WPPs), as well as wind power projects planned for construction until 2024 has been carried out.
\end{abstract}

\section{Introduction}

The possibilities of using hydrogen as an environmentally friendly energy carrier and for energy storage have been discussed with varying degrees of intensity since the 2000s. The rise in interest in this topic - both of experts and scientific community - is associated with the concept of a carbon-free economy put forward to date and the prospects for introducing a carbon tax. In accordance with this, the so-called green and blue hydrogens are considered the most popular, the production technologies of which imply zero greenhouse gas emissions into the atmosphere: electrolysis using energy from renewable sources in the first case, steam reforming of methane with $\mathrm{CO}_{2}$ capture - in the second [1].

At the beginning of July 2020 The European Commission published the "Hydrogen Strategy", which includes a set of measures to promote green hydrogen in the European energy sector and decarbonize the economy, including the construction by 2030 electrolysis plants using renewable energy sources (RES) with a total capacity of $40 \mathrm{GW}$ and a production of 10 million tons pure hydrogen. Other regions and countries around the world have also launched large-scale green hydrogen projects. So, Japan, which has many years of experience in research and development in the field of hydrogen technologies and fuel cells, put into operation in 2020 one of the world's largest solar-powered electrolysis stations in Fukushima with a capacity of 1.2 thousand cubic meters of hydrogen per day [2]. Saudi Arabia is pursuing a construction project by 2025 in the "city of the future" Neom electrolysis plant with a capacity of 650 tons of hydrogen per day using energy from wind (WPP) and solar power plants (SPP) with a total capacity of 4 GW. Australia, based on large-scale use of wind and solar energy, plans to achieve by 2027 electrolysis capacity

\footnotetext{
* Corresponding author: nefludmila@mail.ru
} 
production of hydrogen in $1 \mathrm{GW}[3,4]$. The total capacity of the renewable energy-based electrolysis plants under construction and projected in the world is about $50 \mathrm{GW}$, while the projects being implemented will provide an increase in the production of green hydrogen by 3 million tons per year [5]. It should be noted that the most ambitious projects in the field of green hydrogen are announced in Western Europe and East Asia, macro regions closest to Russia and the largest economic partners of the country.

In the Russian Federation in October 2020 the Action Plan ("road map") for the development of hydrogen energy up to 2024 was approved [6]. The purpose of the implementation of this plan is to increase production and to expand the areas of application of hydrogen as an environmentally friendly energy source, as well as the country's achievement of leading positions in the world in its export. The task of developing hydrogen energy is also set in the Energy Strategy of the Russian Federation for the period up to 2035. According to this document, the export of hydrogen from our country should reach 2 mln t per year [7].

Russia has a significant potential for the expansion of hydrogen production, taking into account the reserves and level of natural gas production (blue hydrogen), the nuclear power capacities (yellow hydrogen). Prospects for the production of green hydrogen were considered, in particular, as a method of increasing the Capacity Factor (CF) of existing and under construction renewable energy plants, including hydroelectric power plants (for example, the "Dyakovskaya Ust-Srednekanskaya HPP" in the Magadan region [8]. It is planned to create a hydrogen cluster in Sakhalin Region for the development of hydrogen energy and the export of this type of fuel to Asian countries. Sakhalin's natural gas reserves and large wind potential are considered as a resource base, the use of which will make it possible to produce about 3 million tons of hydrogen per year [9].

Analysis of technical feasibility, resource availability and competitiveness of those projects requires regional assessments of green hydrogen production potential using renewable energy sources and determination of sustainability degree of energy production from wind and solar power plants [10]. Some scientific research with the use of GIS were carried out for the most realistic plans for the development of the green hydrogen industry in Netherlands, Australia, Ukraine, South Africa [11-14].

\section{Object of study and methods}

The objective of the work is to analyze the possibilities and prospects of hydrogen production using renewable energy sources in Russia. Due to the fact that a number of large grid wind power plants have been built in the country in last year, an analysis of the volume of electricity generation at these stations and the level of utilization of installed capacities was carried out. Based on the analysis of regional energy balances, the possible volume of green hydrogen production at present and in the future was estimated, taking into account the increase of electricity generation at wind farms by 2024.

In this the study computational, predictive and analytical methods, economic and geographical analysis and expert assessments were used. Information base for the research were the data of companies - energy producers, the System Operator of the Unified Power System (SOUPS) of Russia and statistical data of Federal State Statistics Service of Russia and the Association Market Council of Russia.

\section{Results and discussion}

There is an active increase in the capacity and productivity of WWP and an increase in electricity production by other plants at renewable energy sources and nuclear 
power plants In Russia (Table 1). Increase in energy production from WPP in Russia was provided by the putting in operation of WWP of total capacity 85 MW in 2019 (Ulyanovsk region), 843.8 MW - in 2020 and 80 MW - in January 2021.

Table 1. Electricity generation by power plants of various types in the Russian Federation in $2019-2020$ [15]

\begin{tabular}{|l|r|r|r|}
\hline Generation station type & \multicolumn{2}{|l|}{$\begin{array}{l}\text { Electricity } \\
\text { million kWh per year }\end{array}$} & $\begin{array}{l}\text { Energy production } \\
\text { change in 2020, } \\
\text { as \% of 2019 }\end{array}$ \\
\cline { 2 - 3 } & 2019 & 2020 & -8.7 \\
\hline Thermal power plants & $679,881.0$ & $620,565.1$ & +9.0 \\
\hline Hydroelectric power stations & $190,295.4$ & $207,416.3$ & +3.3 \\
\hline Nuclear plants & $208,773.3$ & $215,682.1$ & +331.5 \\
\hline Wind power plants & 320.8 & $1,384.1$ & +54.3 \\
\hline Solar power plants & $1,284.9$ & 1982.3 & \\
\hline
\end{tabular}

The analysis of the potential of grid WWP in Russia for the production of green hydrogen was carried out on the basis of calculations of the Capacity Factor (CF) of all wind farms operating in $2020[15,16]$, which amounted to $34 \%$. On the basis of this value were conducted evaluation of electricity generation prospects of WPP in Russia, $\mathrm{CO}_{2}$ emissions reduction and the hydrogen production (the specific power requirement: 55600 $\mathrm{kWh} / \mathrm{t} \mathrm{H}_{2}$ ). Carbon dioxide reduction potential calculation by increasing WPP capacities carried based the assumption, that the generation of electricity in Russia is accompanied by emissions of about $500 \mathrm{gCO}_{2} / \mathrm{kWh}$ on average. As a less optimistic scenario electricity generation for WPP, estimates for were also made for $\mathrm{CF}=17 \%$ (Table 2).

Table 2. Assessment of the annual potential for green hydrogen production and $\mathrm{CO}_{2}$ emission reduction at the operating WWP in regions of Russia as on 02/01/2021

\begin{tabular}{|c|c|c|c|c|}
\hline $\begin{array}{l}\text { Wind Power Plants in } \\
\text { Russian Federation }\end{array}$ & $\begin{array}{l}\text { Capacity, } \\
\text { MW }\end{array}$ & $\begin{array}{l}\text { Generation } \\
\text { potential, } \\
\text { mln } \mathrm{kWh} \text { /year }\end{array}$ & $\begin{array}{l}\mathrm{CO}_{2} \\
\text { emission } \\
\text { reduction } \\
(\mathrm{Kt})\end{array}$ & $\begin{array}{l}\text { Hydrogen } \\
\text { production } \\
\text { potential, } \\
\mathrm{T} / \text { year }\end{array}$ \\
\hline Ulyanovsk region. Total: & 85.4 & 254.36 & 127,2 & 4570 \\
\hline WPP 1 & 35 & 104.24 & 52.1 & 1870 \\
\hline WPP 2 & 50.4 & 150.11 & 75.1 & 2700 \\
\hline Rostov region. Total: & 346.8 & 1032.91 & 516.5 & 18560 \\
\hline Sulinskaya WWP & 98.8 & 294.27 & 147.1 & 5290 \\
\hline Kamenskaya WWP & 98.8 & 294.27 & 147.1 & 5290 \\
\hline Gukovskaya WWP & 98.9 & 294.27 & 147.1 & 5290 \\
\hline Cossack WWP & 50.4 & 150.11 & 75.1 & 2700 \\
\hline Republic of Adygea. Total : & 150.0 & 446.76 & 223.4 & 8030 \\
\hline Adyghe WWP & 150.0 & 446.76 & 223.4 & 8030 \\
\hline $\begin{array}{l}\text { Republic of } \\
\text { Kalmykia. Total: }\end{array}$ & 216.6 & 645.12 & 322.6 & 11,600 \\
\hline Yustinskaya WWP & 15 & 44.68 & 22.3 & 803 \\
\hline Salynskaya WWP & 100.8 & 300.22 & 150.1 & 5400 \\
\hline Tselinskaya WW & 100.8 & 300.22 & 150.1 & 5400 \\
\hline Stavropol region. Total: & 210 & 625.46 & 312.7 & 11240 \\
\hline Kochubeevskaya WWP & 210 & 625.46 & 312.7 & 11240 \\
\hline $\begin{array}{l}\text { Total for the Russian } \\
\text { Federation }(\mathrm{CF}=34 \%) \text { : }\end{array}$ & 1008.8 & 3004.60 & 1502.3 & 54000 \\
\hline Total for the $\mathrm{CF}=17 \%$ & & 1502.30 & 751.2 & 27000 \\
\hline
\end{tabular}

Source: completed by the authors based on [15], [16]. 
Analysis of power balances (PB) of Russian regions in 2019 showed that the most power-deficiency areas are Krasnodar Territory $(\mathrm{PB}=-14078.8 \mathrm{mln} \mathrm{kWh})$, Orenburg $(\mathrm{PB}=$ - $5606.8 \mathrm{mln} \mathrm{kWh}$ ), Ulyanovsk $(\mathrm{PB}=-2892.8 \mathrm{mln} \mathrm{kWh}$ ) Regions, the Republic of Adygea $(\mathrm{PB}=-1573.6 \mathrm{mln} \mathrm{kWh})$ and the Republic of Kalmykia $(\mathrm{PB}=-451.9 \mathrm{mln} \mathrm{kWh})$ [17]. The construction of large wind farms in these regions will increase the reliability of power supply, improve the environmental situation and ensure the reduction of $\mathrm{CO} 2$ emissions, which is especially important for the Krasnodar Territory, the most important recreational region of Russia. At the same time, it should be noted that in the Republic of Kalmykia with low total energy consumption, plants on renewable energy sources (SPP 164.5 MW, WPP - 216.6 MW) built in 2019-2024 will put Republic of Kalmykia among the energy surplus regions of the Russian Federation. As a result, renewable energy produced in this Republic can provide additional potential for the production of green hydrogen.

The most promising regions for the production of $\mathrm{H} 2$ are energy-surplus regions: Rostov Region ( $\mathrm{PB}=+25238 \mathrm{mln} \mathrm{kWh})$, Murmansk Region $(\mathrm{PB}=+3951 \mathrm{mln} \mathrm{kWh})$, Stavropol $(\mathrm{PB}=+3632 \mathrm{mln} \mathrm{kWh})$ and Perm $(\mathrm{PB}=+5054$ million $\mathrm{kWh})$ Territories [17]. In the Rostov Region Wind power plants with a total capacity of $350 \mathrm{MW}$ are currently in operation, which at a $\mathrm{CF}=34 \%$ can provide about $1040 \mathrm{mln} \mathrm{kWh}$ of electricity per year. Estimates show that this generation from WPPs can provide $208 \mathrm{mln} \mathrm{m}^{3} \mathrm{H}_{2}$ or about 18700 tons of green hydrogen per year (at $\mathrm{CF}=17 \%$ - respectively $520 \mathrm{mln} \mathrm{kWh}$ and 9350 tons).

According to the conducted constant adjustment of wind farm construction plans in the Southern Federal District, in the Rostov Region it is planned for 2021 to put into operation another 3 new windfarm: in Azovsky, Zimovnikovsky and Kamensky administrative areas (AA) with the total capacity of 260 MW. LLC "Enel Rus Wind Azov" will commission a wind farm with a capacity of $90 \mathrm{MW}$ in the Azovsky AA, JSC "NovaWind" - in the Zimovnikovsky AA with a capacity of 120 MW, and PJSC "Fortum" and the Russian Direct Investment Fund will commission the second phase of a wind farm with a capacity of $50 \mathrm{MW}$ in the Kamensky AA. The Enel Company, constructing the Kola WPP in the Murmansk Region with the capacity of 201 MW, which will be launched at the end of 2021, is already preparing a project to use its electricity for hydrogen production.

We can also highlight Kaliningrad ( $\mathrm{PB}=+2663 \mathrm{mln} \mathrm{kWh}$ ) and Leningrad Regions (PB $=+22552 \mathrm{mln} \mathrm{kWh})$ as the energy surplus and very prospective territories. Although there are no large WPP projects yet, these regions are characterized by a high wind energy potential, experience in using wind power plants and high export opportunities for green hydrogen production due to location in the west part of Russia. Pre-design studies have begun in Leningrad Region for the 68.4 MW Sviritsa WPP, with a high export potential for hydrogen production.

In 2013-2020, tenders procedure were held to select projects for the construction of RES power plants in the regions of Russia until 2024 in accordance with the policy to support the development of renewable energy on the terms of Capacity Supply Agreements (CSA). It's planned to construct $3539.1 \mathrm{MW}$ of wind farms in 13 regions of Russia by 2024 [16]. Our calculations of the prospects of electricity generation at the wind farms of Russia, planned for construction till 2024 and the prospects for green hydrogen production on them based on the average $\mathrm{CF}=34 \%$ and $\mathrm{CF}=17 \%$, are presented in Table 3 . 
Table 3. Regional distribution of WPP projects construction in the Russian Federation in accordance with the results of the 2013-2020 "Competitive selection of investment projects for the construction of RES generating facilities": Prospects for the green hydrogen production

\begin{tabular}{|l|r|r|r|r|}
\hline Region of the Russian & $\begin{array}{c}\text { Wind farm } \\
\text { projects } \\
\text { capacity until } \\
\text { 2024, MW }\end{array}$ & $\begin{array}{c}\text { The potential of } \\
\text { electricity } \\
\text { generation, by } \\
\text { CF=34\% } \\
\text { mln kWh } / \text { year }\end{array}$ & $\begin{array}{c}\text { Prospects for } \\
\text { green } \\
\text { hydrogen } \\
\text { production, } \\
\text { t/year }\end{array}$ & $\begin{array}{c}\text { WWP built } \\
\text { on } \\
1.02 .2021, \\
\text { MW }\end{array}$ \\
\hline Astrakhan Region & 183.00 & 545.05 & 9800 & - \\
\hline Volgograd Region & 77.40 & 230.53 & 4140 & - \\
\hline Krasnodar Region & 1052.50 & 3134.77 & 56340 & - \\
\hline Rostov Region & 503.69 & 1500.19 & 26960 & 346.80 \\
\hline Republic of Adygea & 250.00 & 744.90 & 13390 & 150,00 \\
\hline Republic of Kalmykia & 226.10 & 673.42 & 12100 & 216.60 \\
\hline Stavropol Region & 173.95 & 518.09 & 9310 & 210.00 \\
\hline Ulyanovsk Region & 316.00 & 941.11 & 16920 & 85.40 \\
\hline Republic of Tatarstan & 100.00 & 297.84 & 5350 & - \\
\hline Murmansk Region & 350.97 & 1045.33 & 18790 & - \\
\hline Orenburg Region & 75.6 & 225.17 & 4050 & - \\
\hline Perm Territory & 189.90 & 565.60 & 10170 & - \\
\hline Kurgan Region & 40.00 & 107.14 & 1930 & - \\
\hline TOTAL by $\boldsymbol{C F}=\mathbf{3 4 \%}$ & $\mathbf{3 5 3 9 . 1 1}$ & 10630.24 & 191070 & $\mathbf{1 0 0 8 . 8 0}$ \\
\hline TOTAL by $\boldsymbol{C F}=\mathbf{1 7 \%}$ & & 5315.12 & 95500 & \\
\hline
\end{tabular}

Source: completed by the authors based on [15], [16].

To determine the volume of prospects for hydrogen production at WPP built under the CSA program in Russia, two scenarios have been considered:

- the use for hydrogen production only "green" electricity produced by WPP located in energy-surplus regions with an established structure of electricity consumption. At the same time, in energy-deficient regions, WPP will operate on a network to supply power to the population or industrial production.

- the second scenario assumes the use of all the electricity generated for green hydrogen production. The second scenario will be relevant if the prices for green hydrogen by European importers will be at a sufficiently high level.

Thus, according to the first scenario, the potential for hydrogen production using the energy of WPPs with annual $\mathrm{CF}=34 \%$ can be up to 80 thousand tons of green hydrogen per year, and according to the second scenario - more than 190 thousand tons per year (at $\mathrm{CF}=17 \%$, respectively $40 \mathrm{kt}$ and $95.5 \mathrm{kt}$ of green hydrogen).

\section{CONCLUSION}

Russia is facing - in accordance with the global trend of energy transition and decarbonization of the economy - the tasks of hydrogen production using renewable energy sources, wich require a large amount of studies on research programs. The analysis of world experience showed, in addition to the need to develop technological issues, also the importance of regional assessments of the prospects for the production of green hydrogen, both for domestic consumption and for export purposes. By now, a wind industry has been created in the Russian Federation, with a localization level of more than $65 \%$, and a rapid pace of increasing the installed capacity of WPPs. Wind electricity generation growth in 2020 amounted to $331 \%$ in comparison with the previous year. By February 2021 the total capacity of wind farms in the country is already 1008.8 MW, a number of projects are nearing completion. The operation of these 
wind farms makes it possible to avoid $\mathrm{CO}_{2}$ emissions due to the non-use of a fuel of 1502.3 thousand tons per year. The assessment made by the authors based on the data on the generation of WPPs in 2020 showed an average annual value of CF of $34 \%$. In a number of energy-deficient regions of the country, WPP power generation is necessary to reduce the electricity supply from other regions over long distances. Other regions where wind farms are constructed or planned by 2024 (Rostov \& Murmansk Regions, Republic of Kalmykia, Stavropol \&Perm Territories) are energy surplus. According two considered scenarios of the green hydrogen production prospects for energy storage and for export using the energy of WPP in Russia after 2024 predicted values of 190 thousand tons (full use of the generated electricity by the WPP) and 80 thousand tons (work on export hydrogen only for WPPs in the energy-surplus regions of Russia) were obtained. However, in years when the wind characteristics will be much lower than the average, the average annual WPP can drop to $17 \%$. In such years, the potential for hydrogen production will be 2 times lower.

The study for prospects of green hydrogen production requires also an assessment of the possibilities of using the energy of hydroelectric power plants in Siberia and East Regions, by increasing their $\mathrm{CF}$, and the huge wind energy potential of the northern and eastern regions of Russia [https://gisre.ru/maps/wind-data\#pot]. This is beyond the scope of this study and is planed to research in the future.

\section{References}

1. T.Mitrova, Y.Melnikov, D.Chugunov, Hydrogen economy - a path to low-carbon development (Energy Center of the Moscow School of Management Skolkovo, Moscow, 2019)

2. A. Mastepanov, A. Hirofumi, Energy Policy, 11, 62-73 (2020)

3. The Future of Hydrogen. Report prepared by the IEA for the G20, (Japan. June 2019)

4. Hydrogen: A renewable energy perspective (Abu Dhabi, IRENA, 2019).

5. Hydrogen Insights. A perspective on hydrogen investment, market development and cost Competitiveness. Report 2021 (Hydrogen Council, 2021)

6. Action plan "Development of hydrogen energy in the Russian Federation until 2024". (Order of The Government of the Russian Federation No. 2634-r dated 10/12/2020)

7. Energy strategy of the Russian Federation for the period up to 2035 (Order of the Government of the Russian Federation No. 1523-r dated 07/09/2020)

8. A.Kopteva; L.Kalimullin, P. Tcvetkov, A. Soares, Energies 2021, 14, 718 (2021)

9. Prospects for Russia in the global hydrogen fuel market. Expert-analytical report / edited by D. Kholin (EnergyNet, Moscow, 2018)

10. A.Pareek, R. Dom, J. Gupta et al, Materials Sc for Energy Technol, 3, 319-327 (2020)

11. S. Kudria, I. Ivanchenko, B. Tuchynskyi et al. Intern J of Hydrogen Energy, 46, 1, 157- 168 (2021).

12. T.R. Ayodele, J.L. Munda Intern Journal of Hydrogen Energy, 44, 33, 17669-17687 (2019)

13. A. N. Chrysochoidis, MR Ad JM van Wijk, Intern. J. of Hydrogen Energy, 45(46), 25096-25108 (2020)

14. D.Milani, A.Kiani, R.Mc Naughton, Intern. J. of Hydrogen Energy, 45(46), 24125 24145(2020) 
15. Report on the functioning of the UES of Russia in 2020, System operator of the Unified Energy System, (M. Ministry of Energy, 2021) URL: www.so-ups.ru

16. The official website of the Association "Market Council" URL: https://www.npsr.ru/ru/market/vie/index.htm

17. The official website of the Federal State Statistics Service of Russia URL:https://rosstat.gov.ru/enterprise industrial 